First Peoples Child \& Family Review

A Journal on Innovation and Best Practices in Aboriginal Child Welfare Administration,

Research, Policy \& Practice

\title{
The politics of kith and kin: Observations on the British Columbia government's reaction to the death of Sherry Charlie
}

\section{Gerald Cradock}

Volume 3, Number 1, 2007

URI: https://id.erudit.org/iderudit/1069524ar

DOI: https://doi.org/10.7202/1069524ar

See table of contents

Publisher(s)

First Nations Child and Family Caring Society of Canada

ISSN

1708-489X (print)

2293-6610 (digital)

Explore this journal

Cite this article

Cradock, G. (2007). The politics of kith and kin: Observations on the British Columbia government's reaction to the death of Sherry Charlie. First Peoples Child \& Family Review, 3(1), 15-33. https://doi.org/10.7202/1069524ar

\section{Article abstract}

This paper examines the events that occurred in British Columbia following the death of a First Nations child placed in a Kith and Kin arrangement. The paper, drawing extensively from internal government reports that were only just recently released to public, provides an "insider's" view of government sponsored child welfare polices and practices in relation to First Nations child welfare agencies and the communities they serve.
This document is protected by copyright law. Use of the services of Erudit (including reproduction) is subject to its terms and conditions, which can be viewed online.

https://apropos.erudit.org/en/users/policy-on-use/ 
First Peoples Child \& Family Review

A Journal on Innovation and Best Practices in Aboriginal Child Welfare

Administration, Research, Policy \& Practice

Volume 3, Number 1, 2007, pp. 15-33

\title{
The politics of kith and kin: Observations on the British Columbia government's reaction to the death of Sherry Charlie
}

\author{
Gerald Cradock
}

A central difficulty for First Nations' child

welfare agencies is that they operate in a world

policy initiatives over which First Nations have which is not of their own making. On the one hand, First Nations' agencies are required to operate within a national funding formula created by the federal government predicated upon a forensic, after-thefact model of child protection where preventative services are not recognized. On the other hand, the delegation model the federal government requires places First Nations' agencies firmly within the legal and administrative practices of provincial child welfare jurisdictions and bureaucratic apparatuses even where federal funding is inadequate, or does not contemplate, provincial laws, policies, and practices. This means that despite whatever attempts First Nations may make towards a truly 'Aboriginal' form of child welfare and social work, such attempts are consistently undermined by legislative and

Abstract
This paper examines
the events that occurred
in British Columbia
following the death of
a First Nations child
placed in a Kith and
Kin arrangement.
The paper, drawing
extensively from internal
government reports that
were only just recently
released to public,
provides an "insider's"
view of government
sponsored child welfare
polices and practices in
relation to First Nations
child welfare agencies
and the communities
they serve.

Lack of influence and control by First Nations' agencies over their own practices means these agencies must constantly adapt to legislation, policies and initiatives which are rarely, if ever, conceived with First Nations' conditions and aspirations in mind. In this sense, and despite the obvious over-representation of Aboriginal families within provincial child welfare systems, provincial practices ought not be described as deliberately obstructive. Rather, they are an assemblage of technologies, practices, and policies created and organized to service the multiple interests present within any government apparatus. As Foucault (1991) famously remarked, the modern state is not a monolithic monstré froid acting with a single purpose. Rather, it is more like one of Tinguely's 'fantastic machines' filled with parts 
and processes created elsewhere and assembled into an incoherent whole which, despite its apparent ineffectiveness in achieving expected results nevertheless gets things done (Rose 1999). In the case of child welfare, this fantastic machine removes children from their parents, dubs some caregivers low risk and others high risk, makes foster payments, employs social workers, counselors, and the rest of the broad panoply of the 'psy' complex. From this perspective, government policies and practices are not irrational, but they are necessarily uncoordinated if only because they cannot control either the unexpected, or the actions and interests of divergent groups over whom the state is supposed to govern.

The delay in completing the Director's Report into the death of Sherry Charlie in British Columbia sparked multiple reviews of government policies and practices. They provide an object lesson in how government apparatuses operate, and how First Nations become trapped within forces and interests over which they have little or no practical control. Further, it demonstrates how a single tragedy can mobilize and serve as a nexus for multiple interests whose appearance on the stage might be brief, but whose effects may be wide-ranging and relatively long-lasting. Superficially, Sherry Charlie's death may be seen as yet another avoidable child protection tragedy in a long list of such tragedies. In particular, it seems to demonstrate British Columbia's child protection authorities' 'failure to learn' the lessons of the Gove Inquiry into the death of Matthew Vaudreuil more than a decade previously. However, as Nigel Parton (2004; 2006) has shown with respect to inquiries into U.K. child protection tragedies, such an analysis fails to account for the very real changes that have occurred in child protection practices in general, and in British Columbia specifically. In particular, such a superficial analysis fails to ask whether the changes introduced in the wake of such inquiries as the Gove Inquiry, and the contemporaneous recommendations of the Legislative Review Panel, may have created new conditions of ambiguity and thereby introduced new risks and new possibilities for error.

This paper will review events occurring after the death of Sherry Charlie with a view toward elucidating the hazards faced by First Nations' child welfare agencies drawn into larger child welfare policies which may, in point of fact, have little or no bearing on how First Nations actually conduct child welfare in their communities and how they would wish to develop those services in the future. The paper draws heavily on various government documents - most originally prepared for audiences internal to government but now publicly available due to the profile the case has taken on both within the popular press and in British Columbia's Legislative Assembly. While some of the documents have been severed to meet privacy requirements, the documents nevertheless present an unusually frank 'insiders' view of government sponsored child welfare practices and policies.

In a sense, the paper is in the "what we can learn' tradition so prevalent for commentaries and inquiries into child welfare tragedies. However, the focus is different; rather than look at the adequacies of case practices, or the efficiencies (or lack thereof) of child welfare policies and apparatuses, the paper seeks to understand the intricacies of the 'art' of government and the place First Nations' child welfare agencies play within that art. Despite the claim that politics should not influence the 
child welfare project, ${ }^{1}$ this paper assumes that child welfare is fundamentally political since it creates debate about the meaning of childhood, the appropriate independence of families from the state, and the degree to which children - or indeed any citizens - can claim 'safeguarding' as an objective of government. Moreover, the politics of child welfare raise questions regarding the appropriate role of government functionaries and experts in preserving established practices when confronted with influence wielded by elected officials and other interest groups seeking to further their own political, economic, and social agendas.

\section{Some Background}

No one disputes that Sherry Charlie was killed by her male caregiver ${ }^{2}$ while in a kith and kin placement ${ }^{3}$. Outside of that fact, there is little agreement as to whether her death was the consequence of a specific breakdown in expected social work practice (as Jeremy Berland $^{4}$ indelicately put it to Usma ${ }^{5}$ staff, a situation in which "heads usually roll") (Morley 2006, p. 46), or whether it was simply a confluence of legislative and policy decisions in which children were placed in danger because of expected social work practices. Specifically, whether these expected social work practices were rooted within the social work ethos and knowledge base, or whether they were a response to conflicting policy requirements rooted within political initiatives reflective of a political philosophy of appropriate governance. This is so because, in addition to the fact of Sherry Charlie's death, there are at least three other facts of which to take account. First, the provincial government of the day had severely curtailed spending in the area of child protection. Second, the government had pursued a policy of decentralizing responsibility away from the provincial government and into the hands of regional arm's length organizations. Third, the provincial government had closed the Office of the Children's Commission (which formerly would have investigated Sherry Charlie's death as a matter of course) and the Office of the Child and Youth Advocate (who would have provided an avenue for family members and other interested parties to publicize their concerns). No account of Sherry Charlie's death can be complete without an understanding of these government initiatives and where they fit into the recent history of British Columbia's child welfare history.

The decade of the 1990s was a time of great turmoil for British Columbia's child welfare system $^{6}$. The death of Matthew Vaudreiul, and the claim of his mother's lawyer that it was the 'system' that had failed the boy sparked the Gove Inquiry into his death (Cradock 2003). This inquiry rapidly expanded into an inquiry into the entire child protection system as it was then constituted in British Columbia. The inquiry produced a total of 119 recommendations for change. For brevity's sake, the many recommendations can be grouped into several themes. First, Gove argued for "child centered" practice because he believed social workers placed too much emphasis on supporting families instead of protecting children - their real clients. Second, Gove believed that all services to children should be placed under a single umbrella rather than scattered through various government departments and ministries. Third, while believing that it was the provincial government's responsibility to create policy and set standards, Gove proposed decentralizing the delivery of services to 'Children's Centers' operating at the community level. Finally, Gove believed child protection services were unaccountable to the 
public and secretive in nature. In particular, Gove did not believe the child protection system could be trusted to investigate its own errors. He therefore recommended the establishment of an independent officer responsible for investigating all children's deaths and all critical injuries together with a mandate to review government child welfare policies and practices.

The NDP government of the day accepted all of Gove's recommendations. The opposition Liberals also endorsed Gove and additionally promised they would not oppose any extra expenditure necessary to implement the recommendations. Accordingly, a Transition Commissioner was appointed and the work of reforming children's' services and instituting the Children's Commissioner began. In the event, the Children's Commissioner did not become an Officer of the Legislature but instead was constructed as reporting to the AttorneyGeneral - although the enabling legislation did give considerable room for independent action including freedom to inquire into any subject and the ability to issue independent reports.

Meanwhile, the NDP government had also commissioned a Review Panel with a view to overhauling child protection legislation. This Review Panel differed from Gove in two important ways. First, the Panel actually became two Panels since its Aboriginal members formed their own Panel and issued a separate report. Second, the Panel was composed of community activists and advocates. This choice of focus was deliberate since the NDP entered office convinced that the existing child protection system was punitive in nature, did not place sufficient emphasis on the need for family support, and was too remote from those it acted upon. The ensuing legislation reflected the Panels' general views by emphasizing "least intrusive" measures. In addition, the Panels argued for local service delivery and control, and the creation of an independent advocate for children and families ${ }^{7}$.

The Gove Inquiry and Legislative Review Panels agreed on the need for more localized service delivery, but they differed sharply on just about everything else. Where Gove wanted a child protection system concentrated on the safety of children, the Review Panels wanted a supportive system preoccupied with least intrusive practices. Where Gove sought local delivery but centralized control of services, the Review Panels sought highly independent local authority. Finally, where Gove wanted a Children's Commissioner to, in effect, police the child protection system, the Review Panels sought a powerful and independent advocate for children and families.

Of the two institutions it is the Gove inquiry that received the most press attention and the one that is exclusive invoked by the press in connection with British Columbia's child protection problems. This enables criticism of the system to be couched within a discourse of 'failure' to implement Gove's recommendations. This oversimplifies the situation not least because Gove said little or nothing about First Nations agencies ${ }^{8}$. The reorganization of child protection that came in the wake of these Reports created a number of contradictions about the purpose of the new Ministry of Children and Families. The legislation that was supposed to guide its practice was predicated on least intrusive methods and protection from heavy handed government interference. On the other hand, the ministry's structure and policy environment was created largely in response to Gove and emphasized the primacy of children's safety and a culture of 'defensive' social work 
(Cradock 2004; Parton 1996) ${ }^{9}$. Indeed, central to Gove's model of child centered practices was the concept of 'risk' and the belief that social workers can and ought to base their practice on scientifically based risk assessment. Furthermore, the Children's Commission created an environment in which social work action was effectively policed from outside the responsible ministry, yet the ministry was also required to respond to interests advanced by the Child and Youth Advocate which, as a product of the Review Panel's recommendations, predictably tended to advocate for least intrusive and supportive measures.

Caught in the middle of all this change, First Nations agencies continued to pursue their attempts to gain control over child welfare through the delegation model. Despite the many complementary things said in the various reports about Aboriginal culture's attitudes to family and children, there is no evidence that First Nations' agencies were conceived by the provincial government as fundamentally different to the child protection system at large. Hence, there was no specific legislation with respect to First Nations' children and no real recognition of First Nations' particular status within policy and practice. The principal policies that emerged from the provincial chaos were never specifically designed for First Nations or to address the unique needs of First Nations' agencies.

\section{The Liberals come to power}

In 2001 the NDP government was replaced by a Liberal government under the premiership of Gordon Campbell. Despite calls for child protection to become depoliticized, the Liberals had used the Gove Inquiry Report to relentlessly criticize the previous government while they were in opposition. Famously, a part of the
Liberal platform was to "end the constant changes" within the child protection system. Further, the Liberals had specifically promised they would protect child protection from budget cuts. However, upon their election the Liberal government announced budget cuts to the renamed Ministry of Children and Family Development (MCFD) of some 20\% (later reduced to 11\%) (BCASW 2006, p.8). They also announced plans to create regionalized agencies, and reduced the number of children in care. In addition, as part of a review of the core functions of government it was announced the Jane Morley would conduct a review of the Children's Commission and Child and Youth Advocates Office with a view to removing any jurisdictional overlaps.

While there could be no principled defense of the budget cuts, the move towards regionalization had some grounding in both the Gove Inquiry and Review Panel's belief in the efficacy of local service delivery. Framed as empowering communities, the general idea was approved by many community and advocacy groups who had previously endorsed this aspect of Gove and the Review Panel. However, in the light of announced budget cuts there was concern that regionalization was less an exercise in community empowerment and more a means of hiding or justifying the cuts. Similarly, the view that there were too many children in care resonated with those who supported the Review Panels' least intrusive approach and those who had observed the startling increase in numbers of children in care that had followed in the wake of Gove's insistence on child centered social work practice. In any case, during Sherry Charlie's lifetime, the prospect of radical budget cuts and another major reordering of the child welfare system preoccupied senior management within the ministry. Further, with respect to the 
regionalization of child protection there was by no means consensus within senior management as to whether the model was useful or practical (Morley 2006, pp. 4, 15).

Meanwhile, Jane Morley's core review of the Children's Commission and Child and Youth Advocate had indeed found overlaps and functions which she believed were not part of the core functions of government. Accordingly, both Offices were abolished and Morley was soon installed as a new Child and Youth Officer. Both Morley and the government claimed that the new position was independent but, in fact, it was designed more as an arm of the AttorneyGeneral's office since the position reported to the Attorney-General rather than the public at large. Responsibility for reviewing children's deaths was transferred to the Coroner's Office (although, in fact, only three were done due to budget cutbacks in that office) (Hughes 2006, p.133), little or no direct advocacy on behalf of specific children or groups was contemplated (in the belief that the Ombudsman could fulfill that role although, here too, budget cutbacks made it unlikely), and there would be no more "second guessing" of ministry policies and practices (Morley 2001, p.15). Instead, the Child and Youth Officer would be restricted to reviewing internal ministry processes in order to ensure that the ministry was, in fact, following its own policies.

\section{Regionalization}

In British Columbia responsibility for the investigation of child abuse and the care of children found to be in need of protection has been traditionally vested in the office of one person. Under the CF\&CS Act (passed in the wake of the Review Panel's Report), it was possible for more than one Director to be appointed. This possibility was not realized by the NDP government because the appropriate section of the Act was never proclaimed. However, when the Liberals began to pursue regionalization the usefulness of multiple Directors was obvious. The province would be divided into semi-autonomous regions each with its own Director. This goal was partially realized insofar as five regions were organized and each had a Director appointed as part of their executive responsibility. For First Nations, the creation of five regions is presently contemplated (Hughes 2006, p.69).

While the Directors are nominally responsible for children captured under the CF\&CSA, it is useful to remember that Gove had introduced a new category of child to child protection discourse in British Columbia; the "child known to the ministry". This child may have had very little contact with the ministry but insofar as contact had been established a kind of responsibility 'creep' had taken place. This 'creep' had been exacerbated by the activities of the Children's Commission whose investigations covered all child deaths and therefore any circumstances under which a child might have been "known to the ministry" with a corresponding expectation that such knowledge ought to have prevented a child's death. Nigel Parton (2006) notes a similar kind of expansion of responsibilities in the U.K. where he claims child welfare agencies are no longer predicated upon protecting children but rather are charged with 'safeguarding' children from non-specific and speculative harm. Thus, the Director's responsibilities had subtly expanded well beyond the strict letter of the law. More will be said about this below in connection with kith and kin agreements.

In the event of a child's death, the new regime designed by Morley assumed that if the death 
was suspicious it would be investigated by the Coroner's Office, any claims by the child's estate would be represented by the Public Guardian and Trustee, any implication that the death could have been avoided by the child protection system would be internally investigated by means of a 'Director's Review', and each apparatus' conduct would be monitored by the Child and Youth Officer. Sherry Charlie's death exposed the weakness of this organizational structure insofar as the Coroner's Office was not routinely carrying out investigations into children's suspicious deaths ${ }^{10}$, the Public Guardian and Trustee had no reason to know Sherry Charlie had died, the Director's Review was lost in a kind of limbo for three years, and the Child and Youth Officer appears not to have known that the Director had commenced an investigation.

Sherry Charlie was a Nuu-cha-nulth child "known to" Usma, the Nuu-cha-nulth child protection agency. However, she and her family were also "known to" MCFD who, in fact, had access to many, perhaps most, of the pertinent records with respect child welfare concerns ${ }^{11}$. Since responsibility for reviewing Sherry Charlie's death fell to the Director, the immediate question was which Director would conduct the review. On the one hand, as an Aboriginal child in receipt of services from an Aboriginal child protection agency, responsibility fell to David Young as the provincial Director. On the other hand, since the child had received services and was part of the records of the Port Alberni MCFD office, responsibility fell to Jane Cowell, the Director for the Vancouver Island Region. Yet, since Usma was an independent agency operated under the auspices of the Nuu-chanulth Nation, Usma claimed equal standing with these provincial officials. Officially, the review was to be conducted in "partnership" between Cowell, Young, and Usma. Indeed, Usma agreed to help pay the costs of the Director's Review. However, in the event, the terms of reference for the Review were finalized by Cowell and Young. Usma was not consulted about the final terms of reference and was, effectively, sidelined from the process ${ }^{12}$.

\section{Director's Reviews}

Directors do not conduct their own Reviews. Rather, they rely on staff assigned to the task to investigate the facts, write a summary of the facts, provide recommendations, and then submit their report for the Director's signature. Perhaps due to the intense criticism internal reviews had received from the Gove Report, the Ministry had developed a template for Director's Reviews which ensured a similarity of format, issues addressed, and presented a reasonable face to the Child and Youth Officer. The central issues of any Director's Review were: Did Ministry staffs adhere to policy? And, if they did not, or if there were mistakes, has the Ministry learned from the mistakes? In effect, a Director's Review was part confessional and part learning device. It was, however, purely internal except for the possibility of the Child and Youth Officer querying its factual base or its interpretation of those facts. Director's Reviews were never designed to be public documents.

The delays associated with the Director's Review into Sherry Charlie's death appear to have been the result of a disagreement as to who retained authorship of the Review. The Ministry decided to retain Nicholas Simons to conduct the Review. Simons was apparently trusted by senior Ministry staff but he was also the Director of a delegated First Nations child protection agency. According to Jane Morley's (2006) report, Simons was untrained 
in the normal format of Director's Reviews and already had serious reservations about the way kith and kin agreements were arranged by the Ministry. Thus, the delay of the Review is explicable within two separate contexts. On the one hand, Simons did not feel himself bound by the 'template' he was given during a one day meeting with Ministry staff, and on the other hand, he felt the Review was 'his' Review which gave him the freedom to make whatever recommendations he saw fit. This led to endless debates as to whether his Review fit the format of what a Director's Review ought to look like, and further debates as to whether his recommendations exceeded his mandate insofar as Simons did not see his task as limited to the question of whether Usma staff had adhered to policy but whether the policy was, in itself, problematic.

Simons' position was tenuous. He was simultaneously the voice of at least two Directors, but he was also the voice of Aboriginal social work. Indeed, while the documents do not support the assertion, it seems reasonable that the selection of Simons as the 'voice' of the Director was largely predicated upon his position within First Nations' social work and protection apparatuses. Therefore, his 'untrained' status was, on the one hand, a liability since he had not been disciplined within the formats of the Ministry's internal workings and expectations but, on the other hand, his position within First Nations' social work added a legitimacy and prestige unavailable to the usual MCFD functionaries. Reading the Morley account, one gets the impression that Simons was bewildered by what seemed to him needless bureaucratic nitpicking while the bureaucrats complained that Simons did not seem to realize his role was not to question policy but merely to determine whether policy had been adhered to. Yet, as Simons attempted to demonstrate, a serious problem connected with the death of Sherry Charlie was what, exactly, constituted policy in the first place. This was so because the terms of reference included the question of whether Usma was in compliance with a draft policy, delivered by fax, and accompanied by no training or interpretation. Given that Usma is a First Nations agency whose masters are not provincial bureaucrats but members of the Nuu-chah-nulth Nation, it is entirely reasonable to question why Usma social workers should be held responsible for a draft policy which they did not draft and which at least one of their colleagues (albeit from a different Nation) had serious reservations about.

\section{Kith and Kin}

Child protection legislation has always been closely circumscribed within liberal states. This is because liberal states value the family as both the primary source of socialization, and the ultimate location of responsibility. Families are both the final bastion against state interference, and the primary means by which affective relations are installed and promulgated. The child protection project is also informed by the traditional European notion of children as possessions of their fathers. Hence, to remove a child from its family is amongst the most serious actions a state can take. Yet, the child abuse "movement" (Hacking 1995) has argued for unfettered state power to prevent harms being visited on children. The debate between the privacy and efficacy of the family, and the necessity of preventing harm to children created by those families, is apparent in the differing positions of the Gove Report's concern for 'child-centered' social work practice and the Review Panel's call for 'least intrusive' practice. Almost no one will claim that families are inherently abusive. Rather the claim is that 
some families contain pathological members, or some families suffer sufficient social exclusion that, despite best intentions, they cannot be trusted to protect children.

Kith and kin agreements are based at a midpoint between these assumptions. The theory of kith and kin agreements accepts that some parents are unable to care for their children (but may well be able to care about their children) but this does not preclude other family members being able to care for such parents' children. Much of the rhetoric in favor of an 'Aboriginal' approach to social work is predicated upon the view that Aboriginal children are linked to extended family in a way that children in modernist states are not. Kith and kin arrangements are predicated upon this linkage between children and their extended family.

In British Columbia, kith and kin arrangements are permissible because the CF\&CSA allows for the transfer of custody of children between adults $^{13}$. Thus, as was the case with Sherry Charlie, parents of a child may lose, or agree to, the transfer of the custody of their children to any other person who is 'kith and kin'. Not surprisingly, such agreements are attractive to any parent faced with the possibility of losing custody due to protective action on the part of the state. From the state's perspective, this form of solution is attractive since it not only upholds the sanctity of the family; it also alleviates the state of the full costs and responsibility of taking children into its direct care. As Donzelot (1979) would describe it, kith and kin agreements occur within the 'social', the mobile and boundaryless area where the state and the family overlap.

In the tradition of the Review Panel with its emphasis on least intrusive social work interventions, kith and kin agreements are desirable because they maintain family and community integrity. However, as Simons and the British Columbia Association of Social Workers (BCASW) (2006, p.11) observed, they are also attractive to governments predicated upon curtailing government expenditure. Kith and kin agreements re-place responsibility for children 'at risk' from the state and onto family members - even where the 'risks' experienced by children are demonstrably created by the activities of the state. In the case of First Nations, this means First Nations family members are 'responsibilized' for the genocidal tendencies of the Canadian state. In British Columbia, the number of children in kith and kin agreements equals the number of children in care of the state (ibid). The reduction of children in care envisioned by a cost cutting government has been realized by an emphasis on placing children with their kith and kin.

That said, while kith and kin agreements may be free, there is a provision for minimal support ${ }^{14}$. In Sherry Charlie's case, the particular fiscal agreements required by the tripartite agreements between Usma, the federal government, and the provincial government meant that a kith and kin agreement was the most cost effective and politically defensible strategy. Hence, the provincial government underwrote the placement of Sherry Charlie with the male caregiver who eventually killed her. Sherry Charlie's death, then, represents an intersection of interests; the desire of First Nations to take control of their own child welfare, the desire of parents to maintain some degree of control over their children, the federal government's desire to leave child welfare costs to First Nations and provincial governments, and the desire of a provincial government to reduce the costs of children in care as part of its drive to reduce overall child welfare costs. 
My reading of Jane Morley's report into the delays associated with the Director's Review of the death of Sherry Charlie indicate that this was precisely what Simons was worried about. Simons realized that kith and kin agreements, underwritten by a provincial government more worried about cost cutting than good social work practice, would inevitably result in children placed with unreliable and potentially dangerous caregivers. His emphasis on the problematic nature of the 'draft' policy suggests he was well aware that the provincial government was using kith and kin agreements to do child protection 'on the cheap' while protecting itself from responsibility for any harms that might flow from decisions made, not by local social workers, but by policy-makers in Victoria. After all, how can one be held responsible for not adhering to a 'draft' policy - let alone how could one's head roll?

In theory, the kith and kin agreement under which Sherry Charlie came to live with non-parental kin was an entirely voluntary and private arrangement between relatives. However, it is clear that the child's parents were under the scrutiny of both Usma and MCFD social workers. In this sense, Sherry Charlie occupied the category "child known to the Ministry" which implied that even though she was not in the care of the Director, her safeguarding was nonetheless the responsibility of the child welfare system. Moreover, while her placement was in some sense 'approved' by Usma, the lack of federal funding available for kith and kin arrangements meant that the placement was funded by the province. It is this multiplicity of authorities and responsibilities that confuses the situation.

It is important to realize that Sherry Charlie (and her sibling) was already living with her relatives before the formal kith and kin arrangement was set up. This means the choice and monitoring of placement was the parents' responsibility. However, as a child "known to" the ministry, Usma (as the Director's delegate) had an interest in whether the placement was reasonable. Given that there was no actual policy in place (merely a 'draft' policy faxed to the Usma office), the articulation of Usma's interest was unclear. Was Usma approving the family's private decision? Was it matching the home against some standard and, if so, what was the appropriate standard? If kith and kin arrangements are truly private arrangements then the appropriate standard must be the protection standard of safety and well-being. In other words, Usma would have no legal right to intervene unless it had reason to believe Sherry Charlie was being, or was likely to be, abused ${ }^{15}$. If, however, a kith and kin arrangement is a sort of foster home then Usma and/or MCFD had a responsibility to ensure the placement was appropriate and safe prior to placement. As we have seen, Sherry Charlie was already in the home prior to the kith and kin agreement. If, as the 'draft' kith and kin policy seems to have expected, the home should be approved prior to placement then, in this particular situation, the child would have had to be removed from the home until the necessary checks had been obtained. Obviously, such an action would be hard to justify as anything more than bureaucratic nitpicking. Certainly it would have been contrary to the least intrusive ethos and would not have been in step with the government's direction that there were too many children in care.

In the event, it was decided by Usma to conduct three kinds of checks. First, adults in the home would be subject to criminal records checks. Second, references were to be provided (primarily by family members). These had not been 
completed at the time of Sherry Charlie's death. Third, MCFD was asked to do a 'Prior Contact Check" to see if MCFD knew the family. MCFD had to do this check because Usma did not have access to the provincial database. Unfortunately, MCFD's check was incomplete and inaccurate. A complete check was eventually sent to Usma the week after Sherry Charlie's death.

\section{Are Kith and Kin Agreements Necessary?}

In British Columbia the possibility of transferring custody between kith and kin has always been legally possible under Section 30 of the Family Relations Act (FRA). In this sense, the kith and kin provisions of the CF\&CSA merely replicate what was already possible. However, the FRA does not provide a mechanism for government to subsidize custody transfer. Where such financial support was a barrier, the usual solution was to bring the child into the care of the Director and recruit family members as 'restricted foster parents' ${ }^{16}$. Here, restricted meant the foster home was limited to fostering particular children with whom the foster parents had a prior relationship. Usually this meant family members but could also include friends, teachers, or any other person with an interest in a particular child. While foster payments to such homes were made, the actual amount paid was uniform and the lowest of all foster parent rates. Other forms of financial assistance or assistance in kind might be available if they were for the child's benefit, but such support was always subject to the variability of available budgets.

Custody transfer under the FRA is ideally predicated upon the private nature of families and their internal decision-making ability. Where family members are in dispute the Court makes a determination of the basis of the child's best interests. The Director is not a party to such agreements or determinations ${ }^{17}$. By contrast, restricted foster placements were purely at the discretion of the Director because custody and guardianship rested with that office. The restricted foster parents may have been family members, but their decision-making ability with respect to their foster children was limited by the Director's policies and the practices of the delegated social worker. The important feature of both these types of arrangements was that authority, responsibility, and custody was never in doubt. Put bluntly, the child was either in the custody of the Director or it wasn' $\mathrm{t}^{18}$.

The new wrinkle presented by kith and kin was to combine elements of the private family with elements of (minimal) public support. The central problem with this approach, and the one that preoccupied Simons, is the problem of responsibility. If kith and kin agreements are voluntary and private then neither the Director nor his Aboriginal delegates have any formal reason to intervene. Indeed, to intervene is to intrude into the private world of family. On the other hand, if government is going to subsidize such arrangements does it not have a responsibility to ensure its funds are being spent wisely? Further, is the responsibility limited to how the funds are spent, or does this responsibility suggest a larger responsibility to inspect the conditions of the subsidized child? Indeed, is the child being subsidized, or the family? To whom does the child belong? And, who is responsible for his or her safeguarding?

The problem with Sherry Charlie's kith and kin arrangement was not simply whether somebody should have known she was likely to die, nor that there was no actual policy in place. The problem is inherent in the conflicting ideologies at play in the very concept. 
Arguably, all social work practice engages with ambiguities and it is on that basis social work stakes its claim to professionalism (Abbott 1988). But, it is disingenuous to claim that Sherry Charlie's death was a consequence of professional decision-making under ambiguous circumstances when, in fact, the problem is not one of professional ambiguity, but of legal and policy ambiguity. In other words, what was the basic purpose of kith and kin agreements, and what responsibilities flowed from that purpose? Was it merely to save money? Was it to create a population of 'hidden' foster children? Was it to preserve the integrity of extended families?

\section{The Director's Report}

There is no little irony that it is Jane Morley's report that tells the saga of the various problems and delays in the production of the Director's Report into Sherry Charlie's death since, in her core review, she had assured the government that the Child and Youth Officer - the position she has inhabited almost since its inception - would ensure that such problems would not occur. In any event, it is clear First Nation's agencies had no control over the format of Director's Reviews, the recommendations of the Reviews, or the scope of the Review's circulation. Similarly, there is no indication First Nations were consulted about whether the Director should, in effect, investigate his or her own errors.

Further, as mentioned above, neither the Director's Review nor the subsequent Report from Morley were originally conceived as public documents. Hence, if Berland's observation was true - that heads would roll - there is no guarantee the rolling heads would know why they had been rolled. This is particularly true since the terms of reference for the Review were altered after Usma had agreed to participate and help pay the cost. Finally, limiting the Review to whether policy had been followed rather than whether the policy was flawed indicates a tendency for Director's Reviews to locate scapegoats rather than be self-reflexive about the Director's own policies and practices and the political imperatives that drive them. The net effect is to isolate political decisions about budget cuts and the diversion of children from care from their practical dayto-day effects. In general, this was Simons' view and it was his struggle to escape from the narrow, scapegoating style of Director's Reviews to a more expansive consideration of the entire policy context which seems to have fueled the delay in the Review's completion.

Two versions of Simons' Director's Report are available. One appears to be a complete version of Simons' own report with a number of deletions in order to protect personal privacy. This version contains all of Simons' recommendations and, significantly, gives Simons' name as author. The second version is a six page summary of the original forty seven page report but also contains the ministry's response to Simons' recommendations. Both Simons' recommendations and the ministry's response are highly directive. For example, recommendation four states:

The provincial Director MCFD, to review Kith and Kin guidelines to determine whether they were intended as discretionary guidelines or as a policy requirement. The revised November 2003, Kith and Kin guidelines should be forwarded to all Aboriginal Agencies (Simons 2005, p.38).

The ministry response is:

The Kith and Kin guidelines were initially revised in 2003 and forwarded to all agencies. Since then, they have been reviewed and replaced with Child Protection 
Standard \#5 Kinship Care in the revised AOPSI. All agencies have received copies of the revised standards, and an orientation program has commenced (Summary n.d., n.p.).

All the recommendations and all the ministry's responses have this directive tone and none demonstrate any particular concern for First Nations' issues. This is not because Simons was unaware of the particular issues facing First Nations. For example, in the much disputed "context" section of his report he tries to show how First Nations social work practices are shaped by the particular nature of First Nations' communities. For example, he notes "the inherent difficulties that exist including transportation, communication and safety issues. They do not have access to vehicles when they travel, and their cellular phones do not work" (Simons 2005, p.4). Moreover, the small size of First Nations' communities presents severe impediments for social work investigations; the endemic level of poverty means social workers cannot reference any absolute notion of "community standards", and the "woefully inadequate" resources "do not address underlying social problems" (ibid. p.45). By contrast, the Summary deletes the context section in its entirety.

Similarly, the Summary does not mention any of Simons' principal concerns with respect to kith and kin agreements. Simons notes kith and kin agreements are a least intrusive form of social work action and that they are "a less costly option than foster care, and an option that is being promoted by MCFD as a way to keep children out of care" (emph. added. Simons 2005, p.27). Instead, the Summary emphasizes the degree of adherence by Usma to the draft kith and kin guidelines and the lack of training in the policy as contributing to "some confusion in the Agency re the use of Kith

(c) Gerald Cradock and Kin Agreements" (Summary n.d., p.4).

Morley's review of the Director's Report continues this theme. Morley suggests that where First Nations are involved in such reviews, they should be consulted by the ministry with respect to terms of reference, fact gathering and practice analysis, and the development, implementation and monitoring of recommendations. She further recognizes that such reviews demand more funding and staff resources than most First Nations' agencies can afford and implies the ministry should reimburse them - although she is not specific as to how this would be done (Morley 2006, p.68). Yet, Morley does not really seem to have given much thought to First Nations' agencies capacity to organize their own reviews. The 'partnership' model she seems to be advancing is virtually identical to the model used for the Sherry Charlie review.

Morley also reinforces the theme of expanding social worker responsibility for safeguarding children. Her first recommendation states:

Expand case reviews to cover deaths and critical incidents not just of children in care or children known to the MCFD under the CFCSA, but also of children and youth who have received services under MCFD's broader mandate, when those services and the practice related to them may have significantly affected the outcome of the case (Morley 2006, p.68).

Expanding case reviews seems to contradict Morley's previous position during the core review. However, she is still supportive of internal reviews. In the core review she wrote that "there is minimal value added by an external investigation and review of the deaths of children who die of natural causes in the care of MCFD or who have received service from MCFD" (ibid 2001, p.44). Her reasoning was that such events were best handled internally and specifically 
disputed the Children's Commission's view that external reviews were necessary because "these issues include quality of life, quality and responsiveness of services and funding issues." (emph. added. ibid). Further, while agreeing these were important issues, Morley asserted they could be best addressed by internal reviews. Hence, the political aspect of policy direction and budget allocation are internalized and hidden within the responsible ministry. This position was endorsed by the independent review conducted by Ted Hughes (Hughes 2006, p.26).

\section{The Politics of Aboriginal Child Welfare}

Morley's opinion was not supported by the Coroner's jury at the Sherry Charlie inquest. Their last recommendation is directed at the Premier of the province and consists of a single sentence: "To re-instate the Children's Commission" (Coroner 2006, n.p.). Nor was the press convinced. Story after story in British Columbia's press accused the government of trying to cover-up Sherry Charlie's death, shift the blame for delaying the Director's Report onto Nicholas Simons, and avoiding responsibility for budget cuts. Indeed, the government's 2006 budget which found an additional $\$ 100$ million or more for the child protection system has been dubbed 'Sherry's budget' (Smyth 2006, p.A7).

Usma has also come under public scrutiny. Writing in the Victoria Times-Colonist, Jeff Rud (2006) noted: "Few people outside the Aboriginal and social work communities are aware of their [First Nations agencies] role, but these agencies have direct responsibility for more than 1,300 B.C. children in government care and will spend more than $\$ 40$ million in taxpayer dollars this fiscal year alone" (ibid, D1). This statement is not strictly true since the children are, in fact, in the care of the Director
- a provincial functionary. Moreover, in addition to totaling the tax dollars spent on First Nations' agencies, Rud found a skeptic within the British Columbia Association of Social Workers (BCASW). According to Paul Jenkinson, who is described as a "spokesman", "The problem is how little information the public has about these agencies and how they function and whether the public can expect a uniform level of child protection across the province" (ibid). This argument was subtly supported by Berland who is quoted as saying "But just because the ministry demands equal or better standards from these agencies doesn't mean it can dictate policy" (ibid). Assistant Deputy Minister Lenora Angel is quoted as describing the relationship between First Nations' agencies and the ministry as "an ongoing kind of quality-assurance improvement” (ibid).

This article captures the kind of doublethink with which First Nations' agencies must cope. The 1,300 children are not the legal responsibility of First Nations, but neither are they ordinary members of the British Columbian 'public'. First Nations agencies manage these children because they are First Nations' children. These children do not live lives common to all children in British Columbia due to the disproportionate number and type of social problems they experience. It is disingenuous of government functionaries to emphasize agencies' supposed independence when, in fact, they are captured by provincial law, policy, and budgetary initiatives. Moreover, there is no reason to suppose that given the particular situation of First Nations a 'uniform standard', predicated upon non-Aboriginal circumstances, would be effective.

As the concept of safeguarding all children "known to" agencies became entrenched, the boundaries of responsibility also expanded 
while budgets were cut and an ethos of family responsibility was promulgated. Inevitably this meant children occupying the border area of "known to", but not in the care of, the Director presented a challenge for Usma in deciding what level of intrusion "least intrusive" practices required. Sherry Charlie was not in care, but Usma nevertheless gained responsibility for her safeguarding through the simple act of knowing she existed and with whom she lived. This odd situation is understandable (though perhaps not rational) in the context of mainstream Canadian society where extended family care may need to be actively encouraged by the state, and the privacy of the family is a paramount value. Whether this has any application to First Nations is irrelevant since the mobilizing the safeguarding principle has little or nothing to do with First Nations' traditions and safeguarding capacity.

The Hughes Report reveals another irony. In a section entitled "Modern Approaches to Child Protection" he lays out a series of "least intrusive" measures described as "service transformation". He contrasts this with an "old model" of many years standing (Hughes 2006, pp.98-99). In fact, in principal, the "modern approaches" he describes are almost the same as those described by the Review Panels (which Hughes never cites). Going even further back in time, the principals of least intrusiveness, family support, and reliance on 'community support' were fundamental to the Community Resource Boards that operated in British Columbia between 1973 and 1977 (Cradock 2003). Meanwhile, the 'old model' he describes has only been British Columbia's guiding model since the release of the Gove Report and the 'defensive' social work that was its consequence.
If there is anything new at all in Hughes" "new approach" it is the recognition that jerking child protection between the poles of least intrusiveness and aggressive child removal requires large and stable amounts of public funding. Similarly, funding is required if all agencies involved with children are to engage in information sharing. However, as with the various reports that have gone before, Hughes pays little attention to the ethical shift from protecting children from child abuse to safeguarding children from harm. What this shift in responsibility means for First Nations agencies is anybody's guess. Given the specific conditions of exclusion, isolation, and poverty under which First Nations agencies operate, how reasonable is it to suppose they can expand their function to incorporate a safeguarding ethos? And, given the particular tripartite relationships First Nations operate under, how reasonable is it to suppose federal funding - still predicated on child protection - is going to grow in accordance with this increased responsibility? Ian Hacking (1995) observed that the one stable thing about child abuse is that the boundary of what counts as child abuse keeps expanding. Parton's (2006) safeguarding thesis suggests an exponential expansion insofar as child welfare agencies become responsible for all manner of threats to children's safety. In British Columbia, this expansion is occurring in the context of a 'regionalization' of responsibility which can only have the net effect of shifting responsibility away from the provincial government and on to these regional agencies. In turn, the funding and policies upon which these regional agencies depend is subject to the whims of provincial politics.

As I write this final paragraph, a new Deputy Minister for the Ministry of Child and Family Development has been appointed. Initial 
reports indicate she has begun to work with First Nations and, having set up child welfare systems in South Africa after the collapse of apartheid, may well be more understanding of the global problems facing First Nations and their effect on First Nations' children's safety. Will this goodwill extend to long term practical budgetary and policy commitments on the part of the federal and provincial governments? Only time will tell. Child protection - and now child safeguarding - are fundamentally political arenas. What's here today is often gone tomorrow.

\section{Endnotes}

1. The view that child welfare is too important to be subject to politics was famously articulated by Thomas Gove in his Inquiry Report on the death of Matthew Vaudreuil. In his letter of transmission he wrote: "[M]any of the changes to British Columbia's and other jurisdictions child protection systems over the years have, by and large, been driven more by political considerations than by a principled assessment of what will best meet the needs of children" (Gove 1995, 3: 31). This view was echoed by Joy McPhail the minister responsible for receiving the Gove Report. "This is not about politics. It's about the protection of our children" (Times-Colonist 1995, 1). Then opposition leader Gordon Campbell claimed he would exempt child protection from budget cutting should he become Premier. As we will see, Campbell reneged on this promise as soon as he did, in fact, become Premier.

2. The exact circumstances of Sherry Charlie's death remain subject to interpretation. They are described in the summary case review as:

The child was born on January 17, 2001, the second of two children of the mother, aged 19 , and the father, aged 27 . The parents' first child, a boy, was born on January 18, 1999. The family lived intermittently in Ahousat, Port Alberni and Victoria. There were eleven intake calls relating to the child, her brother and her mother and father received either by the
Ministry or the agency. On August 14, 2002, the child was placed with the caregivers by her mother. On that date, there was a discussion between Ministry staff and Agency staff regarding a Section 8 (Kith and Kin) agreement. The caregivers and family agreed to a plan for both children to be placed with them under a Section 8 Agreement. The Agency placed the brother with the caregivers on August 21, 2002. On August 26, 2002, the caregivers signed the Section 8 agreement.

The child died on September 4, 2002. She was 19 months old. The caregivers' explanation for the death, as reported by the investigating police officers from the Port Alberni RCMP detachment, was that she was pushed down five stairs by her older brother during what was described as a "sibling fight" and died as a result of her injuries. Between September and November, the Ministry conducted a safety assessment of the other children in the home and found them to be safe. Between September 2002 and January 2003, the agency and Ministry received information that the coroner was suspicious about the explanation for the child's death. On January 17, 2003, the coroner released the official pathologist's report indicating that the cause of the child's death was homicide. The RCMP met with the coroner on January 21 and began a homicide investigation. On January 24, 2003, the Agency director met with the RCMP and the coroner. Following a consultation between the Agency and the Ministry, the boy was removed from the home on February 3, 2003. On June 5, the male caregiver was charged with seconddegree murder and remained in custody until October 2003, when he was released pending the preliminary hearing. He is allowed no contact with the family. On Oct. 4, 2004, he pleaded guilty to manslaughter and on Oct. 5 , 2004, he was sentenced to 10 years in jail. (n.a. 2006, 2-3).

3. An anonymous reviewer pointed out that the term "kith and kin" may suggest a variety of differing arrangements across the country. For the purposes of this paper, the definition is the legal definition contained in British Columbia's Child, Family, and Community Services Act 
(see footnote 13 below). To be clear, the purpose of this paper is not take a particular stand on whether kith and kin arrangements are a good practice (although I think they are), but rather to draw attention to the way kith and kin agreements can muddy lines of authority and responsibility for children.

4. At the time he made this statement, Jeremy Berland was coordinating the Director's Review into the death of Sherry Charlie. His official title at the time was Executive Director of the Aboriginal Services Branch of the Ministry of Children and Family Development.

5. Usma is the Nuu-cha-nuth Tribal Council's child welfare agency. It was the first such agency to receive full child protection delegation from the British Columbia government.

6. This section is largely based on my dissertation research in which I reviewed all of the submissions to the Gove Inquiry, the Legislative Review Panels, and a third Report (The Korbin Commission) not relevant here. Readers are directed to Cradock (2003), especially chapter 4 for a full description of the Inquiries, their approaches to child welfare, and their implementation.

7. When Ted Hughes wrote his review of B.C.s child protection system he mentions the Advocate but not the Review Panels. A reader of Hughes who is unfamiliar with this aspect would gain the impression the Advocate's position was created in isolation from the child welfare model advanced by the Review Panels. This helps to explain why Hughes is able to claim the model of 'modern' child protection he advances is somehow new. See below for a further discussion.

8. In earlier research I recall one submission from a First Nations agency that specifically chastised Gove for approaching First Nations on the grounds that a) the Aboriginal Review Panel had already reported and the agency endorsed its recommendations, and $b$ ) Vaudreuil was not an Aboriginal child but many members of the public thought he was. Gove's extension of his inquiry into First Nations' child welfare was thought to be problematic because it furthered the public's misconception. (See: Cradock 2003).

9. In this context, 'defensive' social work refers to child protection practices predicated upon social worker's fear of being scapegoated for children's injuries or deaths. These fears coincide with the dominance of risk thinking in child protection. It is no accident that the number of children in care in British Columbia almost doubled after the release of the Gove Report.

10. The scandal around Sherry Charlie's death is part and parcel of the revelations that, in fact, the Coroner's Office was neither conducting investigations into children's deaths, nor had it done anything with the 955 open files it had inherited from the abolished Children's Commission (Hughes 2006, 129).

11. Sherry Charlie's family was also "known to" other agencies such as the police. In his review, Hughes suggests child protection authorities should use information technologies to link with other agencies for the purpose of acquiring information necessary to pursue its safeguarding mandate. This echoes recommendations for a national database of U.K. children by the Lamer Report into the death of Victoria Climbié. Such a linkage would, of course, exponentially expand the number of children "known to" child protection authorities.

12. For some 18 months Usma thought MCFD's use of the terms 'joint' and 'partnership' meant Usma was one of three equal parties to the review and each would sign off on its contents. Charlotte Rampanen of Usma is quoted by Morley as saying: "And so it was - I was waiting for a conversation that was never going to happen and realized the major decision-maker for some time had been Jeremy [Berland]" (Morley 2006, 27).

13. The provision reads:

Agreements with child's kin and others: A director may make a written agreement with a person who (a) has established a relationship with a child or has a cultural or traditional responsibility toward a child, and $b$ ) is given care of the child by the child's parent. (2) The agreement may 
provide for the director to contribute to the child's support while the child is in the person's care. (CF\&CSA).

14. The BCASW states the maximum support for kith and kin agreements is $\$ 450$ per month. By comparison, regular foster care can reach up to $\$ 10,000$ per month depending on the severity of the child's difficulties. Note this ceiling is not statutory but a policy decision.

15. Reliance on protection standards for intervention into foster homes - let alone kith and kin agreements - was the conclusion of the Children's Commission's Tribunal Panel ruling in its case PD-008. At the time, the Director strenuously argued the Tribunal had erred but was overruled by the Minister. The 'independence' of foster homes was further underwritten by the Supreme Court of Canada in K.L.B. v. A-G (B.C.). In each of these cases, the overriding concern is with the sanctity of the family and the belief that child protection authorities should be severely restricted as the degree of control they exercise over foster children and foster homes. See Cradock (forthcoming) for a detailed discussion of these cases.

16. I should add that the Child in Home of Relative Program permits the subsidization of children in relative's homes. However, this program is part of the provincial income assistance program and therefore unavailable on reserve. Also, the program has no standing in statute - it appears to be a creature of policy.

17. Where the Court requires a 'report' to advise itself on the best decision, the report is composed by an Officer of the Court.

18. However, as noted in footnote 15 above, the actual degree of control the Director could exercise over children in foster homes has been undermined by K.L.B.

\section{Bio}

Gerald Cradock spent some twenty years working in British Columbia's child welfare system, including almost a decade as a child protection worker. In the early 1990s, Dr. Cradock left social work to enter graduate school where he initially studied First Nations' political economy in British Columbia.
His later graduate work concerned the problem of defining child abuse in the context of the Gove, Korbin, and Legislative Review Inquiries in British Columbia. At present, Dr. Cradock is conducting research on the question of whether it is possible or useful to describe contemporary children as 'neo-liberals'. As part of this project, his paper "The Responsibility Dance: Creating Neo-liberal Children" is forthcoming in the journal Childhood.

\section{References}

Abbott, A. (1988). The System of the Professions: An Essay on the Expert Division of Labor. Chicago: University of Chicago Press.

B.C. Association of Social Workers. (2006). "Submission to the B.C. Children and Youth Review”. January. n.p. (Copy in possession of the author.)

B.C. Children and Youth Review. (n.d.). An Independent Review of B.C.'s Child Protection System, conducted by Mr. Ted Hughes Q.C. http://w.w.w.childyouthreview.ca/, Accessed Feb, 282006.

British Columbia. (2006). "Jury Recommendations from the Port Alberni Inquest", News Release. 2006CFD0001-000110. Feb. 18.

Child, Family and Community Service Act [updated to January 16, 2006] [RSBC 1996] Chapter 46. Available online at http://www.qp.gov.bc.ca/ statreg/stat/C/96046_01.htm.

Children's Commission. (n.d.). Tribunal Panel Decision, Complaint Case \#PD00-08. n.p. (Copy in possession of the author.)

Community Panel, Family and Children's Services Legislation Review in British Columbia. Aboriginal Committee. (1992). "Liberating our children, liberating our nations : report of the Aboriginal Committee, Community Panel, Family and Children's Services Legislation Review in British Columbia." Victoria, B.C. 
(1992). "Making changes, a place to start: report of the Community Panel, Family and Children's Services Legislation Review in British Columbia." Victoria, B.C.

Cradock, G. (forthcoming). The Responsibility Dance: Creating Neo-Liberal Children. Childhood. -. (2004). "Risk, Morality, and Child Protection: Risk Calculation as Guides to Practice", Science, Technology, and Human Values, 29: 314 - 331.

(2003). "Governing Through Vague Terms: Child Abuse, Community and Government”, $\mathrm{PhD}$. Dissertation. University of British Columbia.

Donzelot, J. (1979). The Policing of Families. New York: Pantheon.

Family Relations Act [updated to January 20, 2005 [RSBC 1996] Chapter 128. Available online at http://www.qp.gov.bc.ca/statreg/stat/F/96128 01.htm.

Foucault, M. (1981). "Govermentality", in The Foucault effect : studies in governmentality: with two lectures by and an interview with Michel Foucault. Chicago: University of Chicago Press.

Gove, T. (1995). Report of the Gove Inquiry into Child Protection in British Columbia: A commission of inquiry into the adequacy of the services, policies and practices of the Ministry of Social Services as they relate to the apparent neglect, abuse and death of Matthew John Vaudreuil. Vancouver, BC.

Hacking, I. (1995). Rewriting the Soul: Multiple Personality and the Sciences of Memory. Princeton, N.J.: Princeton University Press.

Kines, L. (2006). "Ministry shortcomings cited in native boy's death." The Vancouver Sun. Jan. 14. Vancouver, B.C.: B 1

K.L.B. v. British Columbia. 2003 SCC 51.
Leyne, L. (2005). “Another death hasn't been explained." Times-Colonist. Dec. 14, Victoria, B.C.: A 12

Morley, J. (2006). "Report to the Attorney General of British Columbia under Section 6 of the Office for Children and Youth Act on the Director's Case Review Relating to the Nuu-chah-nulth Child Who Died in Port Alberni on September 4, 2002." February 15. n.p. (copy in possession of the author.)

. (2001). "Report on the Core Services Review of the Children's Commission and Overlapping Services Provided by the Child, Youth and Family Advocate, the Ombudsman, the Coroner and Ministry of Children and Family Development." December. n.p. (copy in possession of the author.)

n.a. (n.d). 'Summary Director's Case Review: S.C. Available online at http://www.mcf.gov.bc.ca/ about us/pdf/summary dir sc.pdf. Accessed February 28, 2006.

Parton, N. (2006). Safeguarding Children: Early Intervention and Surveillance in a Late Modern Society. New York: Palgrave Macmillan. (2004). From Maria Colwell to Victoria Climbié: Reflections on Public Inquiries into Child Abuse a Generation Apart, Child Abuse Review, 13: 80-90.

Rose, N. (1999). Powers of freedom: Reframing political thought. Cambridge: Cambridge University Press.

Simons, N. (2005). Director's Case Review: Death of S.C. A Child Not in Care. Final. n.p. (copy in possession of the author.)

Smyth, M. (2006). "Money too late to save Sherry: Money for kids-in-need just replaces cash Campbell cut," The Province. Feb. 22: A7.

Times-Colonist. (1995). The Gove Report - MacPhail out to start changes, not resign - Only. Nov. 30. Victoria, B.C.: 1 